\title{
Teacher Performance Evaluation: The Importance of Performance Standards
}

\author{
João Casanova de Almeida \\ Universidade Fernando Pessoa, Porto, Portugal
}

\begin{abstract}
The aim of this paper is to help reflect on the key importance of performance standards, considering the transparency and the minimization of subjectivity which are intended to exist on the evaluation of teacher performance. Envisaging management evaluation from the point of view of professional development, it will be taken into consideration the relationship between assessment and teacher autonomy as well as the pondering, apprenticeship and consequent change of each teacher. In accordance with this proposition we will address an essential element for the absolutely necessary transparency in the teacher performance evaluation process, the teacher performance standards, in a supervisory context.
\end{abstract}

\section{Introduction}

In this article, the evaluation approach of teaching performance in a professional development perspective, considering that this position is, therefore, crucial to improve a meaningful and sustainable learning, we present the importance of setting performance standards, within the scope in which is developed the action and the current program objectives.

In the materialisation of the desired professional development, within the evaluation of teacher performance, reference is made to the importance that the supervision cycle acquires, especially in the scientificpedagogical domain, evident in the classes to be observed. The supervision cycle in its three phases, considering the moments antecedent and subsequent to the observation itself, seem to be determinants to foster professional development, as an instrument in the service of teacher performance evaluation.

In this context, the performance standards will be addressed taking into account that they will have to reflect the objectives of the Educational Systems and that according to the context in which each school develops its educational activities, should establish the procedures that lead to the results expected by the school, depending on their Educational project, supported by the strategies considered most appropriate for that purpose in the Activity Plan, and to produce the desired evidence.
Performance standards establish the fundamentals of all action to be executed by the teacher, aiming at professional development and consequently the organizational development of the educational institution [1].

It is in the context of reflexivity and teacher training that this paper is presented, critical to the success of a process that is to be transparent, rigorous and that values merit, through simplified procedures, whether in relation to that present in the evaluation process of teacher performance as issuers of evaluative judgments, either as recipients of those judgments.

This standpoint is fundamental in the preparation of performance standards, given that the necessary attention is not always given to this process, leaving uncovered this element in the teacher performance evaluation process, which importance is crucial.

Therefore, in this paper, as culmination of all theoretical considerations presented for the development of teacher performance evaluation standards we will conclude with a work proposal, illustrative of its construction, relative to the dimension of teaching and learning development, founded on the definition of performance level Good as a reference standard, from which all other performance levels standards are defined.

The focus of this article on the performance standards of teacher evaluation, as a form of professional development, in the search for better learning, is part of a logic committed to increasing the quality of education systems, attentive to their evolution dynamics, in a context of schools with autonomy.

Within this logic, since the teacher is the central element of the educational system, the methodological process proposed for the evaluation of teacher performance takes shape, introducing transparency, justice and equity in the implementation process of the teacher performance standards, taking into account the professional development of the teacher and the added value he can bring to the personal and intellectual development of his students.

\section{Theoretical context}

When we propose to intervene in the educational system, it is important to remember that this system, as 
an open system, is characterized by the interrelationship and interdependence of the different elements its comprised of, as subsystems of the educational system, which in turn forms part of a superstructure in which is included the social system [2].

The awareness of this notion is fundamental to understanding the complexity of the systems and the impact the adoption of any measure of educational policy has on the entire system in the context of dynamics and evolution of educational systems.

In this context, we will consider the stages of educational development characterized by productionoriented education and its dynamics of evolution through the subsequent stages of development of consumer-oriented education, customer-oriented education and innovation-oriented education, in the corresponding period between the post-world war II, coinciding with the emergence of mass economy, and present time. [3]

For a better characterization of the evolutionary process of educational systems in terms of their driving forces, their main characteristics and the determining role, of the development stages of educational systems, previously mentioned in a sequential way, we can observe the following tables [4]:

Table 1. Evolutionary process of educational systems Driving forces

\begin{tabular}{|c|c|c|c|c|}
\hline 离 & $\begin{array}{l}\text { Production- } \\
\text { oriented }\end{array}$ & $\begin{array}{l}\text { Consumer- } \\
\text { oriented }\end{array}$ & $\begin{array}{l}\text { Customer- } \\
\text { oriented }\end{array}$ & $\begin{array}{l}\text { Innovation- } \\
\text { oriented }\end{array}$ \\
\hline \multirow{4}{*}{ 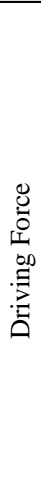 } & $\begin{array}{l}\text { Sustained } \\
\text { Economic } \\
\text { Expansion }\end{array}$ & $\begin{array}{l}\text { Social } \\
\text { Search }\end{array}$ & $\begin{array}{l}\text { School } \\
\text { Account- } \\
\text { ability } \\
\text { Report Card }\end{array}$ & $\begin{array}{l}\text { Institutional } \\
\text { Intelligence }\end{array}$ \\
\hline & $\begin{array}{l}\text { Human } \\
\text { Capital } \\
\text { Formation }\end{array}$ & $\begin{array}{l}\text { Welfare } \\
\text { State }\end{array}$ & $\begin{array}{l}\text { Reducing } \\
\text { Public } \\
\text { Deficits }\end{array}$ & $\begin{array}{l}\text { Management } \\
\text { of Change } \\
\text { Anticipation }\end{array}$ \\
\hline & $\begin{array}{l}\text { Search for } \\
\text { Qualifica- } \\
\text { tions }\end{array}$ & $\begin{array}{l}\text { Economic } \\
\text { Growth }\end{array}$ & $\begin{array}{l}\text { School- } \\
\text { Company } \\
\text { Partnership }\end{array}$ & $\begin{array}{l}\text { Global } \\
\text { Learning } \\
\text { Strategies }\end{array}$ \\
\hline & $\begin{array}{l}\text { Training } \\
\text { Monopolies }\end{array}$ & $\begin{array}{l}\text { Mass } \\
\text { Education }\end{array}$ & $\begin{array}{l}\text { Customer } \\
\text { Satisfaction }\end{array}$ & $\begin{array}{l}\text { Transnation- } \\
\text { al } \\
\text { Competition }\end{array}$ \\
\hline
\end{tabular}

Let us emphasize in this context the evolution from the stage of production-oriented development to the innovation-driven stage of development, and as regards the driving forces, for example, the path from human capital formation to the current pre-emptive management of change, as well as the demand for qualifications to the global learning strategies, adapting these evolutions to the political, economic and social development of each country.

Let us emphasize, with respect to this framework, again, by way of example, the evolution of pedagogies, starting in the post-war period with a pedagogy of education, evolving into a pedagogy of learning, followed by a focus on interactive pedagogy and desirably in our present time the use of a variable geometry pedagogy.

Table 2. Evolutionary process of educational systems - Main characteristics

\begin{tabular}{|c|c|c|c|c|}
\hline 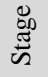 & $\begin{array}{l}\text { Production- } \\
\text { oriented }\end{array}$ & $\begin{array}{l}\text { Consumer- } \\
\text { oriented }\end{array}$ & $\begin{array}{l}\text { Customer- } \\
\text { oriented }\end{array}$ & $\begin{array}{l}\text { Innovation- } \\
\text { oriented }\end{array}$ \\
\hline \multirow{11}{*}{ 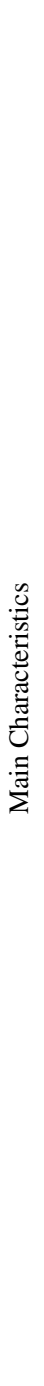 } & $\begin{array}{l}\text { Teaching } \\
\text { Factory }\end{array}$ & $\begin{array}{l}\text { School } \\
\text { Democrati- } \\
\text { zation }\end{array}$ & $\begin{array}{l}\text { Disecono- } \\
\text { mies of } \\
\text { Scale }\end{array}$ & $\begin{array}{l}\text { Negotiating } \\
\text { vs. } \\
\text { Imposing }\end{array}$ \\
\hline & $\begin{array}{l}\text { Assembly } \\
\text { Line }\end{array}$ & $\begin{array}{l}\text { Participa- } \\
\text { tion } \\
\text { (parents, } \\
\text { students) }\end{array}$ & $\begin{array}{l}\text { Co- } \\
\text { accountabil- } \\
\text { ity }\end{array}$ & $\begin{array}{l}\text { Project } \\
\text { Work }\end{array}$ \\
\hline & $\begin{array}{l}\text { Standardiza- } \\
\text { tion }\end{array}$ & $\begin{array}{l}\text { National } \\
\text { Regulations }\end{array}$ & $\begin{array}{l}\text { Custom } \\
\text { Systems }\end{array}$ & $\begin{array}{l}\text { Basic } \\
\text { Networks } \\
\text { Training }\end{array}$ \\
\hline & $\begin{array}{l}\text { Uniform } \\
\text { Prescrip- } \\
\text { tions }\end{array}$ & $\begin{array}{l}\text { Deconcentra } \\
\text { tion }\end{array}$ & $\begin{array}{l}\text { Decentrali- } \\
\text { zation }\end{array}$ & $\begin{array}{l}\text { Constant } \\
\text { Institutional } \\
\text { Redesign }\end{array}$ \\
\hline & $\begin{array}{l}\text { Bureaucrat- } \\
\text { ic Power }\end{array}$ & $\begin{array}{l}\text { Technocrat- } \\
\text { ic Power }\end{array}$ & $\begin{array}{l}\text { Shared } \\
\text { Power }\end{array}$ & $\begin{array}{l}\text { Creative } \\
\text { Power }\end{array}$ \\
\hline & $\begin{array}{l}\text { Supported } \\
\text { Production } \\
\text { of Teachers }\end{array}$ & $\begin{array}{l}\text { Mass } \\
\text { Technology }\end{array}$ & $\begin{array}{l}\text { Individual } \\
\text { itineraries }\end{array}$ & $\begin{array}{l}\text { Horizontal } \\
\text { Manage- } \\
\text { ment } \\
\text { Methods } \\
\end{array}$ \\
\hline & $\begin{array}{l}\text { Exponential } \\
\text { Expenses }\end{array}$ & $\begin{array}{l}\text { Public } \\
\text { Investment }\end{array}$ & $\begin{array}{l}\text { Customer } \\
\text { Fees }\end{array}$ & $\begin{array}{l}\text { Program } \\
\text { Financing }\end{array}$ \\
\hline & $\begin{array}{l}\text { National } \\
\text { Budgets }\end{array}$ & $\begin{array}{l}\text { Global } \\
\text { Financing }\end{array}$ & $\begin{array}{l}\text { Education } \\
\text { Cheques }\end{array}$ & $\begin{array}{l}\text { Financing } \\
\text { at Margin }\end{array}$ \\
\hline & $\begin{array}{l}\text { Teaching } \\
\text { Pedagogy }\end{array}$ & $\begin{array}{l}\text { Learning } \\
\text { Pedagogy }\end{array}$ & $\begin{array}{l}\text { Interactive } \\
\text { Pedagogies }\end{array}$ & $\begin{array}{l}\text { Pedagogies } \\
\text { of Variable } \\
\text { Geometry }\end{array}$ \\
\hline & $\begin{array}{l}\text { Offer } \\
\text { Strategies }\end{array}$ & $\begin{array}{l}\text { Search } \\
\text { Strategies }\end{array}$ & $\begin{array}{l}\text { Educational } \\
\text { Marketing }\end{array}$ & $\begin{array}{l}\text { Strategic } \\
\text { Spin-offs }\end{array}$ \\
\hline & $\begin{array}{l}\text { Student } \\
\text { Assessment }\end{array}$ & $\begin{array}{l}\text { Formative } \\
\text { Evaluation }\end{array}$ & $\begin{array}{l}\text { Results } \\
\text { Evaluation }\end{array}$ & $\begin{array}{l}\text { Perfor- } \\
\text { mance } \\
\text { Evaluation }\end{array}$ \\
\hline
\end{tabular}

The evolution of the pedagogical approach at each moment inevitably determines the focus on the type of privileged evaluation, beginning in the productionoriented education as a focus in the students' evaluation, evolving to the formative evaluation, being followed by the results evaluation and culminating in the stage of innovation-oriented development in performance evaluation.

In line with what we have pointed out in relation to the previous table, let us now observe, in this context, that one of the determining players began, in the first 
stage of evolution, being the teacher, evolving the focus for the student, followed by parents and employers and culminating in educational institutions.

Table 3. Evolutionary process of educational systems - Determining players

\begin{tabular}{|c|c|c|c|c|}
\hline$\underset{\infty}{\infty}$ & $\begin{array}{l}\text { Production- } \\
\text { oriented }\end{array}$ & $\begin{array}{l}\text { Consumer- } \\
\text { oriented }\end{array}$ & $\begin{array}{l}\text { Customer- } \\
\text { oriented }\end{array}$ & $\begin{array}{l}\text { Innovation- } \\
\text { oriented }\end{array}$ \\
\hline \multirow{3}{*}{ 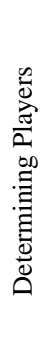 } & Teachers & Students & $\begin{array}{l}\text { Parents and } \\
\text { Employers }\end{array}$ & $\begin{array}{l}\text { Educational } \\
\text { Institution / } \\
\text { Autonomy }\end{array}$ \\
\hline & $\begin{array}{l}\text { Teaching } \\
\text { Unions }\end{array}$ & $\begin{array}{l}\text { Student } \\
\text { Association }\end{array}$ & $\begin{array}{l}\text { Customer } \\
\text { Associations }\end{array}$ & $\begin{array}{l}\text { Associations } \\
\text { of } \\
\text { Educational } \\
\text { Centers }\end{array}$ \\
\hline & $\begin{array}{l}\text { Central } \\
\text { Planning }\end{array}$ & $\begin{array}{l}\text { Peripheral } \\
\text { Planning }\end{array}$ & $\begin{array}{l}\text { Local } \\
\text { Planning }\end{array}$ & Community \\
\hline
\end{tabular}

In the evolutionary process that we have just presented, the transition from one stage of evolution to another does not take place simultaneously in all countries, nor does it evolve in each country completely abandoning a stage, assuming in a block all the driving forces, main characteristics and determining players in the following stage of development.

The evolution takes place in each country with the plasticity that the political, economic and social development determine and the measures of educational politics materialize.

Understanding the evolutionary process of education systems helps us not only to better understand its dynamics, but also to seek, in the light of this knowledge, to increase its quality.

In this context, as we seek to increase the quality of education systems, taking into account its evolution dynamics, we are aware of the difficulties in reaching a consensus among the different players in the process. They prevent a definition of the concept of quality from being unanimously accepted by all [5].

Considering the concepts of: quality as prestige/excellence, understood as the academic and social reputation of the institutions and that distinguishes them from the rest; resource based quality while assuming that quality exists when there are excellent students, qualified teachers and appropriate equipment; quality as results, as a vision of quality focused on the final product, the results; quality as adequacy to purposes, placing the focus on what is intended in practice when defining quality, assuming that it is worth nothing to speak of quality in the abstract, but rather of what is appropriate; and quality as perfection or merit, which promotes a concept of quality based on the consistency of good practices and that concerning processes and products openly bets on perfection, by merit; We will preferably take into account the concept of quality as added value given that we consider it to be the one that best suits a performance evaluation process [6].

The concept of quality as added value is understood in the perspective that an institution has more quality when it has a greater incidence on the change of conduct of the students. We understand that higher quality institutions are those that have the most impact on students' knowledge, on the evolution of their personality and on the development of their career. [7].

The evaluation of teacher performance was not always considered as determinant in improving the quality of student learning. In terms of the demand for this improvement, education systems in their reformist times have focused almost exclusively on improving curricula, changes in school administration and management, and the development of new programs. These nearer reformist moments consider two important concepts, the professionalism of the teacher and the restructuring of the school, embodying in themselves the efforts to reform the teaching in a way more focused on the needs of the students. In this movement of search for improvement of learning, the evaluation of teacher performance has gained evidence. A greater focus on teacher evaluation allows more informed decision making to the improvements that are intended to be sustainable and meaningful of learning, which consequently translates to the greater relevance that is attributed to teacher evaluation. [8]

Considering that teacher assessment can serve two basic purposes, responsibility and professional development, and that the former has focused the attention of most investigations, determining the degree of teacher appropriation, according to the Defined standards, let us focus on the second purpose, although interest in its study has been increasing steadily over the last few years.

Professional development focuses on the collection of data to help teachers grow professionally in the context in which they develop their action [9].

These purposes consider that the assessment of teacher performance should value the formative component of the evaluation. This training approach strengthens the professional development of teachers, taking into account, for this purpose, that the definition of performance standards ensures not only the quality of teachers' actions, and consequently the improvement of their practices, but also the transparency of the evaluation process [10].

The assumption from which we start positions management evaluation towards professional development, bearing in mind the relationship between the assessment and teacher autonomy, produced reflection, verified learning and change in teacher [11]. For this positioning, it is essential understanding that the teacher must position towards education, according to John Dewey, as a reflective practitioner, contrasting reflexivity to routine, which holds three attitudes nec- 
essary for reflexive action: open spirit, responsibility, sincerity [12].

A performance evaluation management system, to become effective, must be perceived as capable of ensuring justice in all procedures and results [13].

It is supposed, in a performance evaluation management system, that evaluation provide information for the decision-making process and strategically allow motivating and guiding teachers around the organization's objectives, improving their performance [14].

In this context, we consider that the professional development of teachers is found in the areas of educational development, which puts the focus on capacity development; professional development, which puts the focus on teacher growth; organizational development, which puts the focus on organization; the development of professional career, which puts the focus on career and personal development, which puts the focus on the growth of the teacher as an individual [15].

In this approach, the resulting performance profile is necessarily the one of a committed professional, based on the qualities desired to all teachers to evidence, consistent knowledge in each area of expertise, skills on evaluation and ability to teach in the classroom context, i.e. the usefulness of its work for the school [16].

In this context, referencing arises as a method of defining a set of referents to ensure that the assessment process is a construction of all involved, consequently adding the desired transparency [17], [18].

Considering the referred assumptions and with all referents selected within the same referencing logic mentioned about the performance patterns, its established for its elaboration the criteria for teaching and learning development; arising from the definition of the criteria, the indicators that are to be observed are defined, allowing verification of whether the criteria are met and their quality [19].

Following the same logical path, from the indicators, schools build their information-gathering instruments, i.e. documents that allow to distinguish the directly or indirectly observable information, and the descriptors for classifying these actions by the teacher in order to identify a given performance level.

The information collection tools allow to, based on the evidence of the action taken by the teacher, describe their performance in comparison with the provisions of performance standards, guided by the descriptors for each of its levels [20].

Therefore, referencing, from the viewpoint of setting performance standards in a teacher performance evaluation process, aims to: build referents; motivating continuation of the systematic search for information; set evaluation dimensions; provide a discussion of the diagnosis; justify and name the criteria that preside over the evaluation [21].

Regarding pedagogical issues, it is very important to consider the importance of the supervision cycle, to enhance the definition of performance standards, considering the pre-observation, observation and postobservation phases.

The supervision cycle allows professional teacher development, based on the interaction between evaluator and assessed, establishing a work frame for the development of the teacher's pedagogical and scientific actions that will be considered holistically. With this purpose, the pre-observation phase allows for a joint work between evaluator and assessed, in a negotiation/collaboration climate, regarding the preparatory moment of the observation, namely objective definition, learning competences to be developed, by the students, contents to be addressed, strategies to be implemented, the evaluation procedures, among others, always keeping in mind consistency with the curricular guidelines and the adaptation to the specifics of the class.

In the class observation phase attention should be focused on the structure of the class, with respect to its phases, duration and sequence, as well as the appropriateness of the type of teaching applied to context, the proposed tasks, the discourse used and the mood of the classroom.

In the post-observation, so that the evaluator can provide feedback to the assessed and consequently promote their professional development, an analysis should be made of what went well and why, of the critical incidents, the least achieved aspects and the possible reasons for it, the strategies to be modified and adjusted, the lessons to be learned for future performance, as well as the identification of needs and ways of responding to them [22], [23], [24].

In line with the training position presented, regarding the evaluation of teaching performance as a factor of professional development, which enhances learning, this phase essentially corresponds to a reflective debate of a formative nature, where the models are problematized, skills and competences are developed, reflexive capacity is improved, action is contextualized, working hypotheses analysed, that is, where the conditions for professional development in its multiple aspects meet [25].

\section{Methodology and procedures}

In a process of teaching performance evaluation, it is of primary importance that it should be presented to both the teachers who will be assessed and the teachers responsible for carrying out this information, as a process in which the parties present themselves with perfect domain of the model being implemented and what it represents as a tool for reflection and consequently for professional development.

For these objectives contribute decisively the design of the performance standards in a thoughtful way and appropriate to the context in which teachers develop their educational action. 
A teacher performance evaluation framework aimed at the professional development of teachers, and bearing in mind the supervision cycle as a privileged instrument for regulating and supporting the improvement of performance in scientific and pedagogical fields, the performance standards bring transparency and decrease the unrest that may exist in the assessment process, allowing evaluators to know which actions to evaluate, who should develop them and who must observe them.

Therefore, any teachers under evaluation know performance places them at a certain level of performance, taking into account their knowledge of existing descriptors in each of the performance levels. We consider in this paper five levels and present them in descending order of performance: Excellent, Very Good, Good, Regular and Insufficient.

As mentioned the development of performance standards is based on the principle of the definition of Good performance level, as a reference standard. In this context, Good is the base standard indicator of what is good professional performance in the different fields and their indicators in a given context.

In the context of each school this is a teacher with a level of performance that is desired to be the standard performance of all teachers in the specific context in which its action is it developed. This is the teacher who combines scientific and professional competence, taking into account the means of provenance of the students and the knowledge they hold, the resources that exist in school and how they are mobilized by the teacher to help develop its professional activity in order to improve the knowledge and skills of their students and consequently the improvement of their school results.

The Very Good level of performance, is the overcoming of the reference standard. Clearly exceeding the standard, Excellent was established as a great teacher effectiveness reference.

These are high performance teachers. Teachers that school boards should recognize a key role, not only in terms of disclosure of their good practices, but essentially at the level of allocation to these teachers a central role in the school's training plan, so that the remaining teachers can reflect on their modus operandi and enhance their professional development, based on the practices of these high-performance teachers, in relation to the norm.

Similarly, Regular performance level evidences that the standard has not been achieved, revealing the teaching difficulties which must be overcome. Insufficient reveals, not only the standard was not reached, but also the teacher has serious deficiencies and inadequate behaviours [26].

In contrast to teachers with high teaching performance, these teachers show a substandard teaching performance, which needs attention from the existing structures in each school, with responsibilities in the evaluation of teaching performance. These teachers must be supported in order to meet other performance standards.

In these situations, teachers must have a specific training plan that, once fulfilled, will allow them to overcome the difficulties revealed in the areas of their action in which the mismatch to the norm has occurred. To this end, these teachers should be supported primarily by high-performing teachers.

To illustrate this, according to the logic described above, we will see through a work proposal how we can build performance standards [27].

Regarding the development dimension of teaching and learning, consisting of the sub-dimensions: preparation and organization of teaching activities, carrying out teaching activities, pedagogical relationship with students, and evaluation process of student learning, observe the following tables:

Table 4. Preparation and organization of school activities

\begin{tabular}{|c|c|}
\hline $\begin{array}{l}\text { Performance } \\
\text { Level }\end{array}$ & Planning of School Activities \\
\hline Excellent & $\begin{array}{l}\text { Scientific correct and peda- } \\
\text { gogically consistent planning, } \\
\text { ability to relate to your area and } \\
\text { others that, although different, } \\
\text { complement learning. Reflec- } \\
\text { tive attitude and autonomous, } \\
\text { promotes strategies and meth- } \\
\text { ods appropriate to the age level } \\
\text { and the proposed syllabus. } \\
\text { Systemic and innovative atti- } \\
\text { tude (not only ICTs). }\end{array}$ \\
\hline Very Good & $\begin{array}{l}\text { Scientific correct and peda- } \\
\text { gogically consistent planning. } \\
\text { Relates several knowledge } \\
\text { areas that complement learning. } \\
\text { Reflective and independent } \\
\text { attitude. Fits systematically and } \\
\text { diversifies strategies to age } \\
\text { level and the proposed syllabus. }\end{array}$ \\
\hline Good & $\begin{array}{l}\text { Scientific correct and peda- } \\
\text { gogically consistent planning. } \\
\text { Relates several knowledge } \\
\text { areas that complement learning. } \\
\text { Fits systematically and diversi- } \\
\text { fies strategies to age level and } \\
\text { the proposed syllabus. }\end{array}$ \\
\hline Regular & $\begin{array}{l}\text { Scientific correct and peda- } \\
\text { gogically consistent planning. } \\
\text { Fits suitable strategies and } \\
\text { methodologies to classroom } \\
\text { context. }\end{array}$ \\
\hline Insufficient & $\begin{array}{l}\text { Planning with many flaws, little } \\
\text { scientific and pedagogically } \\
\text { consistency, or even non- }\end{array}$ \\
\hline
\end{tabular}




\begin{tabular}{|l|l|}
\hline & $\begin{array}{l}\text { existent. It does not adapt or } \\
\text { diversify the strategies, meth- } \\
\text { odologies and resources used. }\end{array}$ \\
\hline
\end{tabular}

Table 5. Conducting of teaching activities

\begin{tabular}{|l|l|}
\hline Performance & $\begin{array}{l}\text { Development of Teaching } \\
\text { Activities }\end{array}$ \\
\hline Manages teaching activities \\
effective and properly. \\
Systematically stimulates inter- \\
est and promotes the self- \\
confidence of students. \\
Speech is clear and precise, \\
appropriate to the age of the \\
students. \\
Often uses resources, themes \\
and innovative strategies pro- \\
moting autonomy in the acqui- \\
sition of knowledge and work- \\
ing methods, resulting in the \\
involvement of all stakeholders \\
in the process of teaching and \\
learning and mainstreaming of \\
knowledge.
\end{tabular}

\begin{tabular}{|l|l|}
\hline & ods. \\
\hline & $\begin{array}{l}\text { Carries out teaching activities } \\
\text { without great effectiveness. } \\
\text { It shows no interest or encour- } \\
\text { ages students to learning. It } \\
\text { does not control the discipline } \\
\text { in the classroom. } \\
\text { Insufficient } \\
\text { Of the students. } \\
\text { Do not use innovative features. } \\
\text { Does not implement strategies } \\
\text { to develop the autonomy and } \\
\text { the acquisition of working } \\
\text { methods. }\end{array}$ \\
\hline
\end{tabular}

Table 6. Pedagogical relationship with students

\begin{tabular}{|l|l|}
\hline Performance & $\begin{array}{l}\text { Teacher-Student Pedagogical } \\
\text { Relation }\end{array}$ \\
\hline Systematically ensures a cli- \\
mate of empathy, self- \\
confidence and autonomy as an \\
essential factor in the teaching \\
/ learning process. \\
Guarantees, effectively, equal \\
opportunities for participation \\
and integration of students. \\
Promotes education for citi- \\
zenship, giving priority to the \\
social consciousness of the \\
student. \\
Meets and consistently sup- \\
ports the students. Provides \\
strategies for overcoming prob- \\
lems. \\
Exercises authority in a bal- \\
anced way. Encourages self- \\
reflection.
\end{tabular}




\begin{tabular}{|l|l|}
\hline & \begin{tabular}{l} 
for participation and integra- \\
tion of students. \\
It is concerned with education \\
for citizenship, respecting the \\
cultural, social and economic \\
students. \\
Attends and supports students. \\
It presents strategies for over- \\
coming problems. \\
Exercises authority in a bal- \\
anced way. \\
\hline Tries to establish a climate of \\
empathy in the classroom. \\
Provides equal opportunities \\
situations of participation and \\
integration of students. \\
Establishes some rules of coex- \\
istence, cooperation and re- \\
spect. \\
Offers availability to meet and \\
support students. \\
Does not exercise authority \\
with balance, not adapting \\
actions to maintain discipline, \\
causing some tension.
\end{tabular} \\
\hline $\begin{array}{l}\text { Has difficulty in affective } \\
\text { relation. } \\
\text { Does not provide equal oppor- } \\
\text { tunities, situations of participa- } \\
\text { tion and integration of stu- } \\
\text { dents. } \\
\text { Neglects the rules of coexis- } \\
\text { tence. } \\
\text { Denotes little willingness to } \\
\text { meet and support the students. } \\
\text { Does not exercise authority } \\
\text { with balance, not adapting } \\
\text { actions to maintain discipline, } \\
\text { causing conflict situation. }\end{array}$ \\
\hline
\end{tabular}

Table 7. Evaluation process of student learning

\begin{tabular}{|l|l|}
\hline $\begin{array}{l}\text { Performance } \\
\text { Level }\end{array}$ & Student Evaluation Practice \\
\hline \multirow{5}{*}{ Excellent } & $\begin{array}{l}\text { Rigorous and reflective aware- } \\
\text { ness that evaluation is critical to } \\
\text { the professional development of } \\
\text { teachers and students. } \\
\text { Use of the criteria (diagnostic, } \\
\text { formative, and summative) and } \\
\text { presentation of the results in } \\
\text { time to the students. }\end{array}$ \\
$\begin{array}{l}\text { Fosters effective and diversified } \\
\text { self-evaluation and analyses, } \\
\text { including educational stake- } \\
\text { holders the findings. }\end{array}$ \\
\hline Very Good & $\begin{array}{l}\text { Properly uses the established } \\
\text { criteria (diagnostic, formative }\end{array}$ \\
\hline
\end{tabular}

\begin{tabular}{|l|l|}
\hline \multirow{5}{*}{} & $\begin{array}{l}\text { and summative) with accuracy, } \\
\text { adequacy, and in good time to } \\
\text { adjust the teaching activities. } \\
\text { Assessment tools reveal accor- } \\
\text { dance with the learning and the } \\
\text { lesson plans. } \\
\text { It features reflective capacity. } \\
\text { Provides regular self- } \\
\text { assessment. }\end{array}$ \\
\hline Good & $\begin{array}{l}\text { Properly uses the established } \\
\text { criteria (diagnostic, formative } \\
\text { and summative) with accuracy, } \\
\text { adequacy, and in good time to } \\
\text { adjust the teaching activities. } \\
\text { Presents reflective capacity. } \\
\text { Fosters regular self-assessment. }\end{array}$ \\
\hline Regular & $\begin{array}{l}\text { Uses the established criteria } \\
\text { (diagnostic, formative and } \\
\text { summative) with accuracy, } \\
\text { adequacy, and in good time to } \\
\text { adjust the teaching activities. } \\
\text { Fosters regular self-assessment. }\end{array}$ \\
\hline Insufficient & $\begin{array}{l}\text { Does not meet the defined } \\
\text { evaluation criteria. }\end{array}$ \\
\hline
\end{tabular}

\section{Conclusion}

We can evidence, through the frame on performance standards used as an example, the importance of the reflection held in each school around the standard performance intended for each teacher to present, as a starting performance ground.

This positioning as a reflective professional allows each of the teachers in each school to think their professional development and meet the goals of the organization, improving their performance in an orientated manner. The process thus becomes transparent by involving everyone, allowing each to be aware that their performance will be framed within a certain level, minimizing the tensions that may occur considering the performance level expected to be reached.

It is also evident in building performance standards that each school should take into consideration the education system objectives and the context in which the learning process occurs, particularly the socioeconomic characterization of school implantation site and its recipients and the resources each school has available to achieve these goals. Thus, the performance standards, bearing in mind the unique situation of each school, have differences from school A to school B, but pursue a common goal, to raise awareness among their students about the importance of learning and improving their performance.

Of great importance in this process of professional development is also the use of the supervision cycle, as a tool of great potential, considering the assertiveness that it can contain throughout the three phases inherent 
to the observation of classes, namely in the scientificpedagogical domain, and the feedback it provides for the adoption of improvement processes. As a final note, it should be noted that all the commitment, transparency and rigor that can be put in the implementation of a teacher performance evaluation process cannot be seen alone as the only responsible for enhancing the quality of learning and consequently improving the education system.

From the systemic point of view, the evaluation leading to its improvement must be analysed in a global way, and teacher performance evaluation is only one of its elements. Thus, in terms of integrated evaluation of the education system, we should consider, in addition to teacher performance assessment:

- The evaluation of educational policies, through the monitoring of the results obtained, in long series, aiming at the consolidation, deepening and improvement of the measures implemented;

- The external evaluation of schools, through selfevaluation and external entity, aiming to introduce improvements in the current school practices;

- The evaluation of the students, systematized and sustained in standards of rigor and requirement and conducive to decision making by the administration;

- The evaluation of the curriculum and textbooks, using scientific and professional associations, as well as personalities of recognized merit in the different areas of education, in order to guarantee its permanent quality and update [28].

It is our understanding that, from the point of view of a global look on the variables that interact in the search for the improvement of students' knowledge, it is absolutely inevitable to always have in mind that in all actions that are triggered on the educational system the requirement and rigor are evident throughout schooling, because only in this way will students have increasingly sustainable and consequently longer paths [29].

Quality education, demanding and rigorous, being one of the essential functions of the State, must be guaranteed to every citizen as a universal right to education. We are thus called upon to reflect on the insufficiency that may be suffered by the partial interventions, on the educational system in search of its improvement. It is no use reconfiguring only the evaluation of teaching performance, or curricula and syllabus if nothing is done in the face of the serious problem in education systems, regarding the lack of requirement and rigor $[\ldots]$.

In a holistically thought-out, demanding and rigorous school, everyone has a decisive and fundamental role to play in achieving the goals of improvement determined in each of the contexts in which each school develops its action.

Parents or guardians must be co-responsible for the course of their students, an inalienable right, and for the fulfillment of the students' general duties, a non-delegable duty.

Young people are asked for commitment, for rigor, they are asked to do the best they can do. They are asked to seek excellence.

Parents and guardians are asked to socially value education so their children can recognize it as a determining factor for success in their preparation for working life [30].

Teacher performance evaluation should be well contextualized, to better realize its value at all, to improve the professional development of teachers and thus improving the performance of their students and their relative value in the set of factors that contribute to the same goal.

It is our understanding and we must work hard to ensure that this understanding has a growing social scope, that the definition of a course for Education in the name of education, training and qualification of our youth should be a matter that reaches broad consensus [...] for the necessary stability it can introduce into the education system.

Education is the greatest vehicle of social cohesion and national unity, transmitting to each of the generations what we have of most importance to provide our youth with the best knowledge and skills to better face the challenges of everyday life, always bearing in mind the values that guide life in society. For this reason, we should not lose sight of the fact that the education of our children and young people is too important to be a stage of political dispute and ideological control.

In this regard, the fact that there are different conceptions of social organization should not constitute an inhibition for policy makers to reach an agreement on the educational policy issues structuring the education system, so that the measures taken can be consolidated and deepened in the name of a good of superior value, the education of our students, their personal, social and professional development and consequently the sustainable development of countries [31].

Education, rather than a political issue, is a matter of state and the interest of the state has to override the political-partisan interest in the name of national interest. [32]

\section{References}

[1] Graça, A. e de Almeida, J.M.C. et al (2011). Avaliação do Desempenho Docente. Lisboa: Lisboa Editora., p. 26.

[2] Bertalanffy, L. (2013). General System Theory. Revised Edition. New York: George Braziller, Inc.., pp. 30-53.

[3] Carneiro, R. (2001). Fundamentos da Educação e da Aprendizagem. Vila Nova de Gaia: Fundação Manuel Leão., pp.95-96.

[4] Carneiro, R. (2001). op. cit., pp .97-119. 
[5] de Miguel, M. (1995). La calidad de la educacion y las variables de proceso y de producto. Cuadernos de Sección. Educación 8., p. 29-51. ISBN: 84-87471-94-3 Donostia: Eusko Ikaskuntza., p. 33.

[6] de Miguel, M. (1995). op. cit., pp. 34-36.

[7] de Miguel, M. (1995). op. cit., p. 35.

[8] Darling-Hammond, L. (1997). Evoluciónen la evaluación de profesores: Nuevospapeles y métodos. In: Millman, J. e Darling-Hammond, L. (Coord.). (1997). Manual para la Evaluación del Profesorado. Madrid: Editorial La Muralla., pp.23-24.

[9] Stiggins, R.J. (1997). Más allá de la competencia mínima: Evaluación para el desarrollo professional.In: Millman, J. e Darling-Hammond, L. (Coord.). (1997). Manual para la Evaluación del Profesorado. Madrid: Editorial La Muralla., pp. 165-166.

[10] Graça, A. e de Almeida, J.M.C. et al (2011). op. cit., pp. 20-21.

[11] Day, C. (1989). Avaliação do Desenvolvimento Profissional dos Professores. In: Estrela, A. e Nóvoa, A. (Org.). (1993). Avaliações em Educação: Novas Perspectivas. Porto: Porto Editora., p.98.

[12] Zeichner, K. (1993). A Formação Reflexiva de Professores. Lisboa: Educa., pp. 17-19.

[13] Cunha, M. e Rego, A. (2009). Liderar. Lisboa: Publicações Dom Quixote., p. 110.

[14] Caetano, A. (2008). Avaliação de Desempenho. Lisboa: Livros Horizonte., p.25.

[15] Riegle, R.P. (1987). Conceptions of faculty development, Educational Theory., p.37. Citado por Stiggins, R., In: Millman, J. e Darling-Hammond, L. (Coord.). (1997). Manual para la Evaluación del Profesorado. Madrid: Editorial La Muralla., p.166.

[16] Scriven, M. (1990). Selección de Profesorado. In: Millman, J. e Darling-Hammond, L. (Coord.). (1997). Manual para la Evaluación del Profesorado. Madrid: Editorial La Muralla., p. 124.

[17] Figari, G. (1996). Avaliar: Que Referencial? Porto: Porto Editora., p.177.

[18] Reis, P. (2011). Construir um referencial para a observação de aulas em contexto de avaliação do desempenho docente: $\mathrm{O}$ contributo da referencialização. In: Machado, E., Alves, M., Gonçalves, F. (2011). Observar e avaliar as práticas docentes. Santo Tirso: De Facto Editores., pp. 52-53.

[19] The Evaluation Center, University of Michigan (2007). In: Ventura, A. (s/data). Avaliação do desempenho e melhoria dos resultados dos alunos. Note: In this text referent is defined as the "dimension for which performance is rated or judged as successful or meritorious".
[20] Graça, A. e de Almeida, J.M.C. et al (2011). op. cit., p. 27.

[21] Alves, M. (2001). In: Ventura, A. (s/data). op. cit. p.249. [22] Vieira, F. (1993). Supervisão: Uma prática reflexiva de formação de professores. Rio Tinto: Edições ASA., pp. 8890.

[23] Reis, P. (2011). op. cit., pp. 50-53.

[24] Graça, A. e de Almeida, J.M.C. et al (2011). op. cit., pp. 62-68.

[25] Diogo, J. (2009). In: Diapositivo de apresentação ao Grupo de Apoio à generalização da Avaliação de Desempenho Docente - DGRHE.

[26] Graça, A. e de Almeida, J.M.C. et al (2011). op. cit., p. 28.

[27] Casanova, R., Costa, M., Silva, G., Sousa, J. (2009). Adapted from the final work presented at the Seminar, MBA in Management and School Organization. Funchal: Universidade Autónoma de Lisboa. In: Graça, A. et. all (2011). op. cit., pp. 29-32.

[28] de Almeida, J.M.C. (2017). La educacion y el discurso político en Portugal: La reforma en la enseñanza secundaria del xv gobierno constitucional (Doctoral dissertation, Universidad de Extremadura). p. 570.

[29] de Almeida, J.M.C. (2017). op. cit., p. 557.

[30] de Almeida, J.M.C. (2017). op. cit., pp. 558-559.

[31] de Almeida, J.M.C. (2017). op. cit., pp. 555-556.

[32] de Almeida, J.M.C. (2017). op. cit., p. 574. 